\title{
Polysèmes
}

Revue d'études intertextuelles et intermédiales

15 | 2016

L'or et l'art

\section{All is not Gold that Glitters: The Gilded Apple (1899)}

Tout ce qui brille n'est pas or: The Gilded Apple (1899)

\section{Pamela Gerrish Nunn}

\section{(2) OpenEdition}

\section{Journals}

Electronic version

URL: http://journals.openedition.org/polysemes/928

DOI: 10.4000/polysemes.928

ISSN: 2496-4212

\section{Publisher}

SAIT

\section{Electronic reference}

Pamela Gerrish Nunn, « All is not Gold that Glitters: The Gilded Apple (1899) », Polysèmes [Online], 15 | 2016, Online since 15 May 2016, connection on 20 April 2019. URL : http:// journals.openedition.org/polysemes/928 ; DOI : 10.4000/polysemes.928

This text was automatically generated on 20 April 2019.

Polysèmes 


\section{All is not Gold that Glitters: The Gilded Apple (1899)}

Tout ce qui brille n'est pas or: The Gilded Apple (1899)

\section{Pamela Gerrish Nunn}

1 Many of the habits, values and ideas of Victorian Britain were subject to challenge and reappraisal between the last years of the $19^{\text {th }}$ century and the first years of the $20^{\text {th }}$. This essay considers how a debutante artist of that time entered the cultural conversation with work which, in that time of great change, drew deliberately on societal valuesspecifically, the valuation of gold. While the artist in question, Eleanor FortescueBrickdale (1872-1945), is familiar enough in the present day, the work selected for examination here has not heretofore received any particular attention. It will be seen that it drew on ideas transmitted through English literature, social habit and Christian belief, to engage with very topical concerns such as the woman question. 


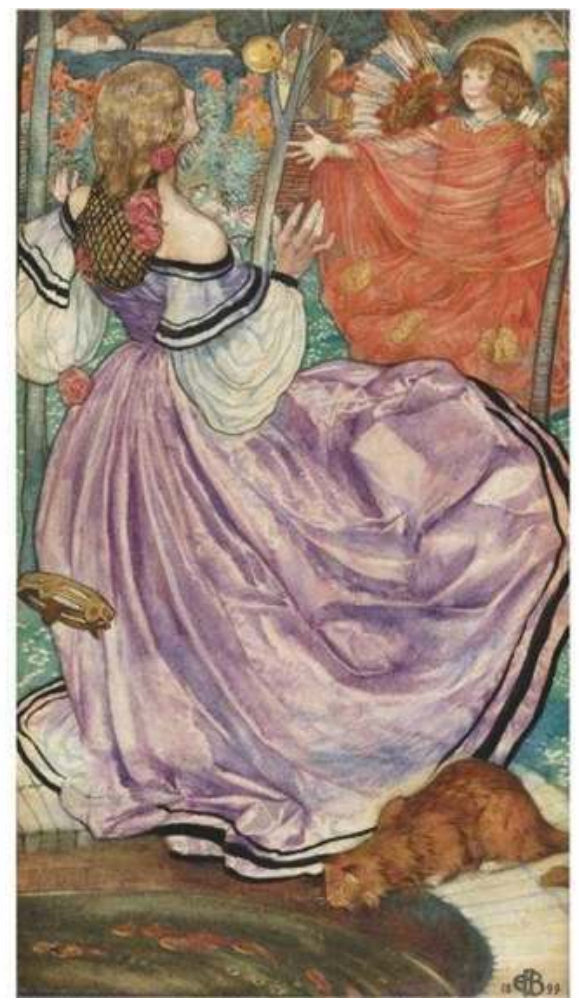

Eleanor Fortescue-Brickdale, The Gilded Apple (1899), 45×26cm, watercolour over pencil, private collection, photo courtesy Sotheby's

2 The Gilded Apple is a watercolour drawing measuring $45 \times 26 \mathrm{~cm}$, signed and dated by the artist. It bears the date 1899 , having been made in preparation for a solo exhibition at the Dowdeswell galleries in London, commissioned that year but eventuating in June 1901. These exhibits were generated over a period which more than one historian has noted "had effectively undermined the confidence and cohesion of mid-Victorian society" (Harrison 209). In the private as in the public sphere, already by 1895, "daily existence was altering at an increasingly rapid pace, with new technology unsettling those who favoured the horse over the bicycle, the fountain pen over the typewriter or the needle over the sewing machine" (Freeman 3). Furthermore, as Juliet Gardiner has observed, "the woman question took on a new colouration as the century drew to its close" (Gardiner 1), with the typically dissident woman of the day questioning "all the attributes usually associated with ideal Victorian womanhood (a penchant for self-sacrifice, a talent for home-making, a willingness to defer to men)", in Sally Ledger's words (Ledger and Luckhurst 75). In the recollection of one culturally connected Victorian aged in his thirties as the century turned, "with the end of the decade came war, unrest, in the air a vague note of change, faint yet perceptible. The old world was passing and I found myself looking out a little anxiously for the New Jerusalem descending from above" (Robertson 287). Additionally, not only had the artist and her public to grapple with the millennium as the calendar turned over the last leaf of the nineteenth century to expose the ominous advent of the twentieth but, when the exhibition opened in June 1901, the most conspicuous fixture of all their lives-and the lives of their parents-had just been dislodged for ever: Queen Victoria's death on 22 January 1901, signalled for several months by her declining health, brought to a definitive close the 64-year era bearing her name. Thereafter lay a future potentially unimaginably different from what had gone before. As one of the admirers of Fortescue-Brickdale's show wrote: "We live, so we often 
hear, in a barren time; inspirers and inspiration have departed, and our only hope is in a hypothetical baby in a hypothetical cradle, who may, even now, be slowly preparing for the consolation of the public" (Sichel 101).

The Gilded Apple was $\mathrm{n}^{\circ} 36$ of the 45 exhibits that Brickdale's show included. It shows the back view of a young woman, wearing a distinctly uncontemporary off-the-shoulder floor-length gown of a shiny purple fabric, in an attitude of surprise, almost falling backwards in that surprise into a pond directly behind her and thus at the feet of the viewer. The momentum of her surprise is indicated by the fact that a coronet which she must have been wearing falls into this pond, in which goldfish can be seen swimming-to the fascination of a long-haired ginger cat crouched in the folds of the woman's hem. The woman's hair is long and contained by a snood, which bears several red roses, one of which has been dislodged by the energy of her movement and also falls towards the pond.

Her surprise has been occasioned by the action of the other figure in the composition, positioned in the top right quarter of the picture space and thus to be read as standing on a rise sloping up and away from the young woman into the upper depth of the pictorial space. This child, of indeterminate sex, wears a diaphanous gown of apricot colour, has wings and a halo of light, and has just tossed towards the woman what looks like a golden apple.

5 This encounter occurs in a stylised meadow, whose grass is dotted with daisy-like flowers, and in which three saplings can be seen growing, though the viewer sees only their trunks and no foliage, so their type can only be guessed at. This meadow is enclosed by a woven willow fence beyond which grows a high hedge and several trees, beyond which again old and rustic-looking buildings block out the horizon. A tiny sliver of sky gives no hint of either the time of day or the state of the weather.

6 The intensity of this composition is representative of the works Fortescue-Brickdale exhibited in her show, which were characterised by critics as decorative moralities relying on allegory and literary reference. The terms in which the work was praised show the impact of her endeavour: "There is a new force to be felt. There is a new lamp kindled. Someone can still see visions"; "She makes no pretence of being a prophetess or a missionary; but she has a gift for the needy world"; "Each painting is a pictured thought [...] these pictures have a message in each for those who look with the eyes of the mind as well as of the body" (respectively, Barnett, Sichel 114, A Welsh Spinster 6). Thus, though many critics claimed to be bewildered by Fortescue-Brickdale's metaphor and allusion, the majority endorsed the work's "keen human interest" (Anonymous 1901). The values mooted in this her first solo exhibition appealed as the maintenance of British society preoccupied the minds of the populace.

7 At this precarious point of transition, this earnest and reflective young artist appeared to offer a vocabulary invested in her society's traditional concepts of wealth and virtue but in novel fashion. Running like a vivid thread through the exhibition were the referents of value by which Victorian society identified that which was good, desirable or moral. ${ }^{1}$ The list of titles evidenced a general concern with behaviour, moral values and the consequences of error and weakness: Love and Adversity, The Cup of Happiness, Truth's bitter Cup, etc.; and, jostling for symbolic weight in Brickdale's display with Christian virtues such as kindness, self-sacrifice, chastity, modesty and loyalty, were the more material forms of good long treasured in the western world such as gold, silver and jewels. 
Silver had contended with gold as the western world's benchmark of monetary worth until the gold standard was established in 1816, and in the last quarter of the nineteenth century the majority of non-specialised opinion accepted American financial journalist David Wells' contention, re-stated in his 1896 publication Robinson Crusoe's Money, that gold had a Darwinian right to its essential financial role, that natural selection identified it thus (see Michaels, Eichengreen).

9 The gold rushes of the middle of the $19^{\text {th }}$ century had reinforced this one commodity's supreme desirability to earlier Victorians and, in the immediate context of Brickdale's exhibition, gold coming during the 1890s from the latest minefields, in southern Africa, emphasised its worth in a headline-making way, with diamonds its precious but lesser companion: and the second Boer War (as it was called then) that gripped the nation turned not only on Britain's identity in this age of imperialism but also on who was to benefit from the gold and diamonds lying beneath the soil of South Africa. Meanwhile at an everyday level, a general ranking of gold first and silver a close second, with these jewels in their wake, was reflected in such mundane conceits as the alignment of raw materials to wedding anniversaries. The establishment of the Nobel prize in 1895 reiterated the gold medal as the award of supreme excellence within the widely applied reward system that still pertains in the western world whereby the gold medal, star, cup or prize was always the supreme award, with the silver second and the bronze third (a further international endorsement of which was the adoption of this trio in 1904 for the recognition of achievement in the Olympic Games). This emphasised in the continuous background of life-as did both alchemy and chemistry-gold's reliability above that of all other precious metals.

10 For the cultured Victorian, gold stood at one end of a spectrum of value which had at its other end such abject commodities as mud or lead, as in Gerard Manley Hopkins' pairing The Leaden Echo and The Golden Echo (1882). Gold's reliability, purity and integrity contrasted also with lesser, unstable or deceptive metals or metal alloys such as ironmaking the couplet from Milton's Lycidas (1637) which refers to St Peter, "Two massy keys he bears of metals twain / The golden opes, the iron shuts amain", a favourite quotation of the would-be erudite Victorian (Lewaski and Hahn 3: 537). And when Tennyson's eponymous Dreamer lamented, "I clash with an iron Truth / When I make for an Age of gold" (Ricks 3: 252, poem n ${ }^{\circ} 461$ ), the reader in 1892 of this his last poem was reminded that gold contains within itself idealism, aspiration, rarity and a vision of perfection that functional, profitable but workaday and ultimately gross iron and lead never will.

11 Indeed one has only to browse the works of Tennyson-a favourite of Brickdale's own-to appreciate how readily the adjective "golden" signalled supreme value not just in the everyday nineteenth-century world but in the Victorian imagination. Accordingly, in the literature of Brickdale's apprentice years, the titles of the first volume of James Frazer's The Golden Bough (1890-1915), Kenneth Grahame's anthology The Golden Age (1895), the second series of Francis Palgrave's already famous Golden Treasury (1897, its first series published in 1861), and William Morris' publication by the Kelmscott Press of the medieval Christian text The Golden Legend (1892) spoke to their fin-de-siècle readers immediately, directly and unconditionally of excellence, supreme worth and lasting value.

12 Scrutinising the contemporaneous visual culture, that same referencing of gold as the byword for ultimate value or perfection occurred alike in the efforts of the individually celebrated (such as Burne-Jones' The Golden Stair 1872, re-exhibited 1892 and 1898) and 
the completely forgettable (such as Alfred Soord's The Golden Hour, 1896). It had the currency of an unproblematic, entirely uncontroversial concept, endlessly recyclable and, although universal, in mediocre hands also glib. Thus one critic described Soord's picture at the time as "one of those classical reveries amounting to little more than a scheme of decoration" (Anonymous 1896), and it had many close relations at the London exhibitions of the 1890s, including not only numerous canvases with exactly the same facile title (such as William Shackleton 1898, Arthur Hacker 1899) but many more with titles only slightly more justified by their subject-matter-such as The Golden Valley (Alfred East 1893), Golden Autumn (Ernest Waterlow 1895), The Golden Shore (Julius Olsson 1897). These were "the numerous landscapists who fill the exhibition with misty pools and goldenyellow trees seen through vapour" reproached for their banality by the Times critic at the 1895 Academy (Anonymous 1895). It is worth noting that Soord's and Hacker's iterations, to present-day eyes possessing nothing memorable at all, attracted enough audience approbation at the time to be featured in the illustrated digest of the respective annual exhibitions, Royal Academy Pictures.

For the painter and sculptor, there was in addition a long established repertoire of stories drawn from the Bible, Shakespeare and Greek mythology and history showing gold as the supreme emblem of that which was good or valuable, yielding dramatic episodes on which could be pinned musings on the human character. These sources facilitated narrative compositions which could claim a higher position in the hierarchy of genres by implying a weighty message. The stories of King Midas, the Golden Calf or the Golden Fleece functioned as cautionary or heroic tales of human greed which urged that the recognition of gold's value be tempered with moral virtue.

The specific theme of relevance here, of gold in the desirable form of fruit, also came from this matrix. Its attraction was expressed beguilingly in a painting that the independent artist Thomas Gotch showed at the 1893 Royal Academy exhibition, A Golden Dream, apparently with no specific narrative intent but relished by critics and, again, popular enough to be selected for Royal Academy Pictures (see Lomax 102ff). This painting's appeal stood upon the various Classical narratives featuring the golden apple widely known in the Victorian period: the Garden of the Hesperides and the eleventh Labour of Hercules, the Choice of Paris, the Race of Atalanta. The figure of golden apples appeared too in other cultural lore known to late Victorian Britain, if less familiar, that could be seen in the run-up to Brickdale's selection of this motif in 1899. At the Royal Academy exhibition of 1891, Val Prinsep exhibited an obscure story from Gibbon's Decline and Fall of the Roman Empire (1776-1788) in which, the exhibition catalogue informed the gallerygoer, as the emperor Theophilus, looking for a wife, "with a golden apple in his hand, slowly walked down the line of contending beauties; his eye was detained by the charms of Icasia, and, in the awkwardness of a first declaration, the Emperor could only observe that 'in this world women had been the cause of much evil'. 'And surely, sir, she pertly replied, they have likewise been the occasion of much good'. This affectation of unseasonable wit displeased the imperial lover: he turned aside in disgust; Icasia concealed her disappointment in a convent; and the modest silence of Theodora was rewarded with the golden apple". The viewer did not need to be a classical scholar to see that this subject, for all its ostensible novelty, was a variation on the Judgment of Paris.

The Norse goddess Freya whom Wagner included in his operatic work Das Rheingold, first performed in England in 1882 but under a renewed spotlight in the 1890s after the first German-language performances of his works in London (1892-4), guarded an apple tree 
whose fruits prolonged the life of the gods to whom she gave them. In more primitive versions of the Norse root, Freya's role is allocated to the goddess Idun, whom J.D. Penrose took for the subject of a painting he showed at the Royal Academy in 1900another exhibit whose popularity can be adduced from its inclusion in that year's Royal Academy Pictures. While these apples are not necessarily identified as golden, it is telling that they are distributed from a golden casket by a flaxen-haired heroine, echoing the golden apples of Grecian pedigree.

Attaching this wealth of context to Fortescue-Brickdale's The Gilded Apple is not entirely straightforward, since the work did not apparently attract any specific critical attention even though the exhibition as a whole was widely reported, as has been demonstrated. The motif of a young woman having golden fruit flung at her must have put many spectators in mind of Atalanta, a princess whose story was told initially by Ovid. Of the Pantheon of women from Greek mythology and history available for repeated reinvention by late-Victorian artists and writers, Atalanta was one of the most visible in a variety of forms across the cultural spectrum. Her identity was as a hunter, worthy protégée of Diana; as athlete; and-so very topically-as independent woman, who swore to remain single unless a man could beat her at running, his reward to be her hand in marriage. When she was at last beaten, it was by Hippomenes introducing golden apples onto the track to distract her from her goal and allow him to get home first. This golden fruit had been given him for this strategy by Venus.

Algernon Swinburne's widely respected account of this character, Atalanta in Calydon, was well-read since its publication in 1865 , but his poetic drama did not include the famous race. But she and it were the subject of a poetical work by William Morris, a favourite author of Brickdale's and one of the most visible poets in 1890s Britain. "Atalanta's Race" is a section of his Earthly Paradise, published in three volumes between 1868 and 1870 and reissued several times in Brickdale's lifetime including in 1890 (Morris 32-9). Another section of the whole, entitled "The Golden Apples", treats of Hercules' acquisition of the golden fruit from the Garden of the Hesperides (327-33).

Atalanta was also mobilised as a point of reference in a variety of stage productions during the 80s and 90s. Because of her famed fleetness of foot, her name was given to boats, race-horses and women's cycling clubs. The Essex Atalanta Cup was instituted in 1900 as an athletics prize to be awarded annually thereafter for the 3-mile flat, utilising Edward Poynter's 1876 canvas of the subject, described by one journalist in 1894 as "his celebrated Atalanta's Race" (Anonymous 1900, Anonymous 1894b). Because of her crucial attraction to gold, mines could be named after her. ${ }^{2}$ There was a monthly magazine for girls called Atalanta published between 1887 and 1894, its frontispiece carrying a vignette of the heroine taken from Poynter's composition. ${ }^{3}$ She stood for female independence and physical stamina of the sort that by 1901 had become associated with the New Woman, a symbolism recognised by feminism's enemies as well as its proponents: "few myths are more repulsive", wrote G.W. Cox for the conservative Edinburgh Review in 1871 (cited Faulkner 124-49).

19 Brickdale's girl in purple is perhaps then a latter-day Atalanta, confronted in her maiden bliss with an unexpected challenge to the happy single life which she would rather maintain. Thus she would embody the theme of independent, self-sufficient modern woman's disdain for heterosexual romance and marriage. This could be the girl who, Atalanta-style, in the words of Ella Hepworth Dixon, "of late [has] shown a disposition to avoid the joys, cares and responsibilities of the linen cupboard", who has manifested 
"shyness at being caught in the matrimonial net" (Dixon 391-2), and whose reluctance to marry could seem crucial in this new situation of uncertainty in which Brickdale's show was created and displayed. She functions if so as the New Woman, "[p]ausing on the century's threshold, / With her face towards the dawn", as D.B.M., an obscure feminist poet put it in the pages of Shafts in January 1894 (cited Gardiner 14),-a woman whose pursuit of self-determination was said by the patriarchs to threaten the survival of established British society.

There is another aspect of the long-standing discourse of Woman here too, for there could be no juxtaposition of female figure and apple in a garden in western culture that did not raise the spectre of Eve and her defining drama. Brickdale's heroine is also then "a daughter of Eve", as the popular contemporary phrase had it, who was tempted just as Atalanta was by a fatal fruit. Implicit in this scene for a conservative viewer then was the question: would this young lady fail her society as the Bible's first woman had failed the human race?

The burden of The Gilded Apple is emphatically, then, from both a progressive and a conservative point of view, the burning question of how the coming generation of women would meet the challenge of the moment. Brickdale's Atalanta is not brought down by a suitor, however, nor her Eve by a serpent, but by the angel-child who takes the place of Hippomenes and the snake alike in introducing the temptation to the heroine. This little innocent disconcertingly displays in its childish frivolity no understanding of the portentousness of its act which, like the appearance of the angel Gabriel to Mary, portends a fundamental change in her life. These cherub-cum-angel-cum-child figures became a staple of Brickdale's repertoire, and are usually, as here, difficult to read in character terms. Had it been more of an archangel and less of a playful child, this figure would have signalled a different kind of announcement to the heroine, but Brickdale's known piety precludes the likelihood of any such intended connection to an act of deceit. ${ }^{4}$ While a glimpse of a quiver of arrows on its back evokes Cupid, it bears no other resemblance to that familiar figure of amorous facilitation and thus remains open to conjecture-although such an identification would strengthen the allusion to the Atalanta narrative, since Cupid is Venus' child and errand-boy and it was Venus who gave Hippomenes the golden apple ploy; this would thereby underline as the primary theme of this scene modern woman's reluctance to succumb to the persuasions of love, while daringly hinting that they are, anyway, specious.

For to appreciate the encounter fully, one must return to the central fact that the fruit occasioning this commotion is not gold but gilded: a glittering prize by which the unwary, gullible or greedy person-necessarily female?-stands to be led astray. Gilding invokes the long-established English saying that cautions against trusting in appearances in the pursuit of advantage, posing a warning to the foolish and the worldly alike who cannot sort true worth from apparent value. In contemporary debate, many were maintaining that the fate of Britain depended on the morality of its womenfolk, and the moral fibre and strength of character of contemporary Woman was argued over by ideologues of all shades. This princess, without company or guidance-no servants hover to abet her wishes, no courtiers recall her to her duties, no parent oversees her, no husband commands her-is distracted by the unexpected treasure flung towards her and, even as we watch, she is in danger of being drawn in by the lure of the deceptive bauble. If she succumbs, as Atalanta and Eve did, what hope is there for the survival of British society in the new and uncertain century? 

of the phrase the artist chose for her title, though it is one which commands little scholarly respect now and would certainly not occur readily to the $21^{\text {st }}$ century scholar of Victorian culture. The "gilded apple" occurred in the enormously popular poetry of the American Ella Wheeler Wilcox, a likely favourite of the artist's, whose taste in literature seems to have been mainstream rather than highbrow. Overall Brickdale's work shares Wheeler's tendency to mingle the moral and the experiential in a sentimentally didactic habit. Wheeler Wilcox was known not only for her poems, conversational and often sentimental moralising verses, snatches of which had already by this time passed into common parlance, but for her life-story, which was packaged for the public in her autobiography, published in 1901: and she had a certain standing as a self-made woman as well as a writer (Wilcox 1901, Wilcox 1918).

"The gilded apple which the world calls pleasure" is invoked in "The Voluptuary", included in Wheeler's first published volume, Maurine and other poems, appearing in 1876 and reprinted many times thereafter through the rest of the century (Wilcox 1976, 197). It begins:

Oh, I am sick of love reciprocated,

of hopes fulfilled, ambitions gratified.

Life holds no thing to be anticipated,

And I am sad from being satisfied. [...]

In a tone which sounds self-righteous to the twenty-first-century ear, but was something of a signature note in Wilcox's writing, the speaker goes on to declare:

The gilded apple which the world calls pleasure,

And which I purchased with my youth and strength,

Pleased me a moment. But the empty treasure

Lost all its lustre, and grew dim at length.

"[B]lest is he who has some aim defeated" and "cursed is he who has no balked ambition", the poem concludes (198).

Disregarding the almost universal normative masculine pronoun of the time in use here, if this reference is applied to Brickdale's image, it sends within the debate about modern Woman a message of caution against the drive to unrestricted experience and selfdetermined satisfaction. Modern woman's opponents never tired of criticising this supposed tendency-fitting with the habit of the poet herself, who created as Angela Sorby points out, "speakers [who] are relentless sensation seekers" (74), whom she authorially critiqued. Being young and unworldly, Brickdale's protagonist cannot know that her attention is solicited by a false treasure, neither Paris' prize nor Yeats' golden apples of the sun, but the gilded apple whose appearance belies its true worth.

Another poetic source certain to have been familiar to both the artist and her spectators bears vividly on this aspect of the picture's freight. Thomas Gray's Ode on the Death of a Favourite Cat (1747) which was included in the 1894 publication of his poems that revived this poet's popularity for the turn of the century (Bradshaw 5-7, poem $n^{\circ}$ II), made explicit use of the idea of false or fool's gold as a temptation to the female. As the authorial voice put it rhetorically, "What female heart can gold despise? What cat's averse to fish?", suggesting a natural or inevitable propensity in the female to be drawn in by gold. And there at the foot of Brickdale's composition is the heroine's feline alter ego, risking herself in pursuit of the gratification offered by the goldfish that swim carelessly in the pond. The woman and the fish are parallelled in the moment of their temptation, both confronted with the lure of gold and poised in a test of sagacity, if not of morality. In 
satirically high-flown verse, the poem concludes in moralising tone, "[....] Not all that tempts your wand'ring eyes / And heedless hearts, is lawful prize; / Nor all that glisters, gold". There is a certain smugness in the authorial voice's certainty that the female does not have the character to tell when gold's apparent value is not worth its acquisitionand, indeed, of course, the cat pays the price for the lack of such wisdom. In this humorous or ironic way, then, the artist reinforces the question of whether her heroine will escape the fate lying in store for her cat.

The common prejudice that women's judgment was unreliable was asserted at all cultural levels. Though it be accepted throughout her society that gold was of ultimate desirability, it was often the vehicle for the misogynistic lesson that she was of such weak metal that she needed to be constantly lectured on, if not punished for her moral insipidity. The Edenic model of vainglorious woman sacrificing the greater good for the flashy advantage of the moment occurred in many contexts. The fiction "Married for Gold", the lead item in the London Journal's January 1894 supplement is a low-level example from the period of this glibly offensive attitude. Its female protagonist has made that dreadful, feminine mistake of valuing gold inappropriately, and with plodding symbolism this feeble character is named Eva. In her opening speech, she says, employing the familiar vocabulary of Woman's biblical unreliability, “I know I oughtn't to be here now, but it was such a terrible temptation..." (Anonymous 1894a, 1).

Observant visitors to the Dowdeswell show might have made a connection between The Gilded Apple and the painting Brickdale had on show at that year's Royal Academy exhibition, running for a month by the time her solo show opened. Also featuring tempting shining fruit, its title The Deceitfulness of Riches could, indeed, fit the present work: several courtly figures repose beneath a tree bearing orange or gold fruits, while a bowl of peaches and soothing music are offered to the central female figure by her various companions. Both titles sound a caution to the susceptible protagonist: here, the heroine is lulled into a false sense of comfort by the offerings her companions make her. These female protagonists, representing susceptible Woman, join Venus, Eve, Atalanta and Gray's (or, Walpole's) cat in a long line of tempted females. ${ }^{5}$ And if a woman can be expected to be drawn into misjudgement by real gold, how much more egregious a moral error would she make in being taken in by its forgery. While Gray castigated her alleged greed and shallowness, the dilemma posited by Brickdale is more nuanced: gold does have an unarguable value, and its acquisition is to a degree not only acceptable but commendable, but a gilded apple is a false prize, just as-in Wheeler Wilcox's cautionary tale-solipsistic pleasure and total gratification are ultimately hollow rewards. The protagonist of The Gilded Apple-despite being a woman but also because she is a womanmust reaffirm her judgment of what is sound, what is false, what is vain and what is enduring, if she is to withstand the uncertainties of the moment and survive this historic watershed.

Like the majority of the protagonists in Brickdale's show, her Atalanta / Eve / New Woman is being tested at an ominously shaky point in Britain's history. Characters on trial in other compositions in the exhibition were also set to test the worth of material wealth against less tangible riches: in The Philosopher's Stone it is love that turns everyday matter into gold; The gift that is better than rubies is wisdom, more to be desired than precious stones; Poor and Content is rich, and rich enough seems to say that the beauties of nature suffice for modest and humble people; Riches turn out, to the pure in heart, to be 
family / love / human relationships; The Cup of Happiness to poor people is simply filled with water, while a rich man thinks he needs material wealth.

The Gilded Apple is a particularly subtle version of this test. And it is evident how much is at stake: from the implied consequences in the minor parts of the scene (the falling tiara, the roses come loose, the cat preying on the fish), the viewer can know that this is a dreadfully momentous encounter. Already startled into losing her composure, our heroine is losing her crown and her roses-and thus her status and her beauty-and perhaps her pet, if Gray's narrative is to guide her fate. At this crucial point in time, the artist posed contemporary women with a vital question not unfamiliar to them in a culture ideologically disposed to test them over and over again: What to do in the face of false gold? How to know what is true, what can be trusted, and what will endure?-This was the demand of the moment that The Gilded Apple proposes that Woman must satisfy.

\section{BIBLIOGRAPHY}

A Welsh Spinster. “A Girl-Painter and her Paintings”. Girl's Own Paper XXIII (October 1901): 6-10.

Anonymous. “Married for Gold”. The London Journal Monthly Supplement 182. 1 January 1894: 1.

Anonymous. "Royal Academy”. The Times. 5 May 1894: 16.

Anonymous. "Royal Academy". The Times. 15 May 1895: 17.

Anonymous. "Royal Academy". The Times. 16 June 1896: 15.

Anonymous. “Ladies' Page”. Illustrated London News. 2 June 1900: 748.

Anonymous. "Notes on Current Events". British Architect. 12 July 1901: 21.

Barnett, Canon. "Such Stuff as Dreams are made of". The Commonwealth. 7 July 1901: 224.

Bradshaw, John (ed.). The Poetic Works of Thomas Gray. London: George Bell and Sons, 1894.

Craik, T.W. "Gray's Humorous and Satirical Verse". Thomas Gray: Contemporary Essays. Hutchings and Ruddick (eds.). Liverpool: Liverpool UP, 1993.

Dixon, Ella Hepworth. "Why women are ceasing to marry". Humanitarian 14 (1899): 391-6.

Eichengreen, Barry. Globalizing Capital. Princeton: Princeton UP, 2008.

Faulkner, Peter (ed.). William Morris, the Critical Heritage. London: Routledge Kegan Paul, 1973.

Freeman, Nicholas. 1895: Drama, Disaster and Disgrace in late Victorian Britain, Edinburgh: Edinburgh UP, 2001.

Gardiner, Juliet (ed.). The New Woman. London: Collins and Brown, 1993.

Harrison, J.F.C. Late Victorian Britain. London: Routledge, 1991.

Ledger, Sally and Luckhurst, Roger. The Fin de Siècle, Oxford: OUP, 2000.

Lewaski, B.K. and E. Hahn (eds.). The Complete Works of John Milton. Oxford: OUP, 2012. 
Lomax, Pamela. The Golden Dream: a Biography of Thomas Cooper Gotch. Bristol: Sansom and Company, 2004.

Michaels, Walter Benn. The Gold Standard and the Logic of Naturalism. Berkeley: U of California P, 1987.

Morris, William. The Earthly Paradise (1868). London: Reeves and Turner, 1890.

Nunn, Pamela Gerrish. "Time and Tide wait for no Man". Symbols of Time in the History of Art.

C. Heck and K. Lippincott (eds.). Turnhout: Brepols, 2002.

Nunn, Pamela Gerrish. A Pre-Raphaelite Journey: the Art of Eleanor Fortescue-Brickdale. Liverpool: Liverpool UP, 2012.

Ricks, Christopher (ed.). The Poems of Tennyson. Harlow: Longman, 1987.

Robertson, William G. Time Was. London: Hamish Hamilton, 1931.

Sichel, Edith. “A Woman-Painter and Symbolism”. Monthly Review 4.12 (September 1901): 101-14.

Smith, C. Lindsay. “A New Brotherhood”. The Art Record 1.2 (1901): 729.

Sorby, Angela. “The Milwaukee School of Fleshly Poetry”. Legacy 26.1 (2009): 69-90.

Swinburne, Algernon. Atalanta in Calydon. London: Moxon, 1865.

Wilcox, Ella Wheeler. Maurine and other Poems. Milwaukee: Cramer, Aikens and Cramer, 1876.

Wilcox, Ella Wheeler. “My Autobiography”. Cosmopolitan 31 (1901): 415-21.

Wilcox, Ella Wheeler. The Worlds and I. New York: George Doran, 1918.

\section{NOTES}

1. The idea of time was also conspicuous in Brickdale's show: see Nunn 2002: 85-97.

2. Such as the Atalanta Consolidated Gold and Silver Mine, which was in the news in Britain between 1890 and 1895 .

3. A reinvention of Every Girl's Magazine, it was edited by L.T. Meade and Alicia A. Leith (both women). The first issue opened with an eponymous poem by Edwin Arnold which was clearly meant to encapsulate the periodical's ethos and message to its readers: "Greek Atalanta! Girdled high; / Gold-sandalled; great, majestic Maid; / Her hair bound back with purple tie", it apostrophised. "Oh girls! Tis English as tis Greek! / Life is that race! [...] scorn not if, before your feet, / The golden fruit of Life shall roll, / truth, duty, loving service sweet, / To stoop to grasp them! So, the soul / Runs slower in the race, by these; / But wins them-and Hippomenes!" The Illustrated London News reviewer read this as "calling on the English girl to start on her race of self-culture in the spirit of the Greek" ("Magazines for October", Illustrated London News, 15 October 1987: 468).

4. I am grateful to Anne-Florence Gillard-Estrada for raising the topic of the Annunciation. For a fuller account of Fortescue-Brickdale's life and work, see Nunn 2012.

5. Ode on the death of a favourite Cat is generally agreed to have been a satirical reference to the rather precious lifestyle of the poet's friend Horace Walpole; see Craik 111-25. 


\section{ABSTRACTS}

In 1901, the neo-pre-Raphaelite artist Eleanor Fortescue-Brickdale became an overnight success with a show of watercolours at the London dealers Dowdeswell's. The works were characterised by critics as decorative moralities relying on allegory and literary reference. Focussing on one of these works, The Gilded Apple, allows an examination of this millennial moment of currency for the moral parable in which the traditional benchmark of wealth, good and benefit-gold-was a central referent.

This intensely worked drawing was not explained by the artist, whom some critics reproached for the opacity of her stories. Notwithstanding, this choice of theme can be connected to her preoccupation with the competing appeal of worldly wealth and moral or spiritual richness, seen in other works in the 1901 exhibition which generally warned against materialism; and to the intensely topical issue of the worth of modern woman's soul or character, which appeared widely in cultural discourse at the time, and in which Brickdale, as a woman, would have been expected to interest herself. Gilding is used here to invoke that long-established English proverb that warns against trusting in appearances in the pursuit of riches. This is not the reliable, genuinely precious golden apple of the beauty contest involving Paris, Helen and Venus; or of the race run by Atalanta, who was decoyed into losing her independence by the lure of golden apples; but a superficially valuable object or prize by which the unwary, gullible or greedy person stands to be duped. Modern woman's role in this moral challenge was the turn-of-the-century society's preoccupation: it is not certain whether it was the artist's, but it could well have been her viewer's.

En 1901, l'artiste néo-préraphaélite Eleanor Fortescue-Brickdale remporta un vif succès lors de son exposition d'aquarelles dans la galerie d'art Dowdeswell de Londres. Ses œuvres, décrites par les critiques comme des morales illustrées, représentaient des sujets allégoriques empruntés à la littérature. L'une de ces aquarelles, The Gilded Apple, permet d'examiner un moment-clé dans l'évolution de la parabole morale où l'or, ce marqueur traditionnel d'opulence et des valeurs du bien et du beau, constitue le référent central.

The Gilded Apple est une œuvre très travaillée dont le sujet ne fait nulle part l'objet d'une explicitation de la part de l'artiste, à qui les critiques reprochaient parfois l'opacité de ses histoires peintes. Il est néanmoins clair que dans cette aquarelle, comme dans d'autres œuvres de l'exposition de 1901, l'artiste oppose richesses terrestres et richesses spirituelles pour mettre le spectateur en garde contre le matérialisme ambiant. En outre, The Gilded Apple invite à réfléchir au statut et à la valeur de la femme moderne, cette New Woman dont l'âme et le caractère faisaient l'objet d'âpres débats au tournant du siècle. Toutefois, la pomme «dorée » du titre («gilded») implique, selon le proverbe bien connu, que les apparences sont trompeuses et que tout ce qui brille n'est pas or. Il ne s'agit pas ici de l'authentique pomme d'or du jugement de Pâris, ni des précieuses pommes d'or grâce auxquelles Vénus parvint à freiner Atalante dans sa course. Au contraire, il est question ici d'une récompense de pacotille, d'un objet précieux seulement en apparence, de manière superficielle, et destiné à ceux ou celles qui, crédules, imprudents ou avaricieux, veulent bien se laisser duper. Dans ces conditions quel rôle la femme moderne joue-t-elle au juste dans cette scène ? Saura-t-elle montrer sa valeur en distinguant l'or véritable de l'illusion dorée ? Là est la question que l'artiste semble poser au public. 


\section{INDEX}

Mots-clés: or, dorure, artistes femmes, mythe, valeur, nouvelle femme

Keywords: gold, gilding, women artists, myth, value, new woman

oeuvrecitee Gilded Apple (The)

\section{AUTHORS}

\section{PAMELA GERRISH NUNN}

Pamela Gerrish Nunn was a Professor of Art History at the University of Canterbury in Christchurch, New Zealand, from 1989 to 2009, and she currently works as an independent scholar and curator. Her fields of specialisation are women artists and women's art during the nineteenth and early twentieth centuries. She is the author of ground-breaking studies such as Canvassing: Recollections by Six Victorian Women Artists (1986); Victorian Women Artists (1987); Women Artists and the Pre-Raphaelite Movement (1989 with Jan Marsh); Problem Pictures: Women and Men in Victorian Painting (1995). Alongside her work as a lecturer, a historian and a critic, Pamela has curated significant exhibitions, among which, the 2006 exhibition From Victorian to Modern, Djanogly Art Gallery, Nottingham; in 2009 at the Tate Britain, the exhibition entitled "Independently Modern" (on pre-Modernist or proto-Modernist women painters); and most recently she curated an exhibition on Eleanor Fortescue-Brickdale, a Pre-Raphaelite Journey, at Lady Lever Gallery, Port Sunlight, in 2012. Her current work focuses on the New Zealand artist Frances Hodgkins (1869-1947), an exhibition of whose work she is curating for the New Zealand Portrait Gallery (Wellington).

Professeur d'Histoire de l'Art à l'Université de Canterbury à Christchurch, Nouvelle-Zélande, de 1989 à 2009, Pamela Gerrish Nunn travaille actuellement en tant que chercheur et commissaire d'exposition indépendant. Pionnière dans l'histoire des femmes artistes et de leurs œuvres au $\mathrm{XIX}^{\mathrm{e}}$ siècle et au début du XX $\mathrm{X}^{\mathrm{e}}$ siècle, Pamela Gerrish Nunn est l'auteur d'ouvrages tels que Canvassing: Recollections by Six Victorian Women Artists (1986), Victorian Women Artists (1987), Women Artists and the Pre-Raphaelite Movement (1989 avec Jan Marsh), Problem Pictures: Women and Men in Victorian Painting (1995). Elle a aussi organisé des expositions importantes telles que From Victorian to Modern à la Djanogly Art Gallery de Nottingham en 2006, Independently Modern (sur les femmes peintres pré-Modernistes ou proto-Modernistes) à la Tate Britain en 2009 et Eleanor Fortescue-Brickdale, a Pre-Raphaelite Journey, à la Lady Lever Gallery, Port Sunlight, en 2012. Ses travaux portent actuellement sur l'artiste néo-zélandaise Frances Hodgkins (1869-1947), dont les œuvres seront bientôt exposées à la Portrait Gallery (Wellington, Nouvelle-Zélande). 